\title{
The Effect of the BC-MK15 Birth Chair on the Labor Pain Intensity in Multipara
}

\author{
Yetti Purnama, ${ }^{1}$ Johanes Cornelius Mose, ${ }^{2}$ Herry Herman ${ }^{3}$ \\ ${ }^{1}$ Department of Midwifery, Faculty of Mathematics and Natural Sciences, Universitas Bengkulu, Bengkulu, \\ Indonesia, ${ }^{2}$ Department of Obstetrics and Gynecology, ${ }^{3}$ Department of Orthopaedics and Traumatology, \\ Faculty of Medicine, Universitas Padjadjaran, Bandung, Indonesia
}

\begin{abstract}
Labor pain causes worry, anxiety, increases the secretion of the adrenaline, adrenocorticotropic hormone (ACTH), cortisol serum levels, catecholamines and the perception of pain. One method to decrease labor pain is through the mobilization and upright position during labor which is facilitated by the BC-MK15 birth chair to relax, decrease catecholamines, increase the release of $\beta$-endorphins and block the transmission of pain stimulus. This study aims was analyze the difference of the effect of using the BC-MK15 birth chair and the conventional bed on the intensity of labor pain in multipara. The design of this study was the posttest-only control group design in 60 samples of the first active phase of multipara at Public Health Centers Garuda, Ibrahim Adjie and Puter of Bandung city in April-May 2017. Each group consisted of 30 for treatment (using BC-MK15 birth chair) and control (using the conventional bed). Assessment of pain scores using the visual analogue scale (VAS) in cervical dilations of $4 \mathrm{~cm}$ (post 1), 7-9 cm (post 2) and $10 \mathrm{~cm}$ (post 3). The statistical test analysis uses the Mann-Whitney test and the chisquare test. There were significant differences among groups which are obtained by the treatment and control of post 2 and post $3(\mathrm{p}<0.05, \mathrm{RR}=0.69$ [0.531-0.896]). In conclusion, there is an effect of using the BC-MK15 birth chair and the conventional bed on the intensity of labor pain in multiparous mothers.
\end{abstract}

Key words: BC-MK15 birth chair, conventional bed, labor pain

\section{Pengaruh Kursi Persalinan BC-MK15 terhadap Intensitas Nyeri Persalinan pada Multipara}

\begin{abstract}
Abstrak
Nyeri persalinan menimbulkan rasa khawatir, kecemasan, meningkatkan sekresi adrenalin, adrenocorticotropic hormone (ACTH), kadar kortisol serum, katekolamin, dan persepsi nyeri. Salah satu metode menurunkan nyeri persalinan adalah mobilisasi dan posisi tegak saat persalinan difasilitasi dengan kursi persalinan BC-MK15 sehingga menimbulkan relaksasi, menurunkan katekolamin, meningkatkan pelepasan $\beta$-endorfin, dan mengeblok transmisi stimulus nyeri. Penelitian ini bertujuan menganalisis perbedaan pengaruh penggunaan kursi persalinan BC-MK15 dan tempat tidur konvensional terhadap intensitas nyeri persalinan pada multipara. Desain penelitian eksperimen posttest-only control group design dengan jumlah sampel 60 multipara kala I fase aktif di Puskesmas Garuda, Ibrahim Adjie, dan Puter Kota Bandung pada bulan April-Mei 2017. Tiap-tiap kelompok berjumlah 30 untuk perlakuan (menggunakan kursi persalinan BC-MK15) dan kontrol (menggunakan tempat tidur konvensional). Penilaian skor nyeri menggunakan visual analogue scale (VAS) pada dilatasi serviks $4 \mathrm{~cm}$ (post 1), 7-9 cm (post 2), dan $10 \mathrm{~cm}$ (post 3). Pengujian statistik menggunakan analisis Uji Mann-Whitney dan uji chi-square. Didapatkan perbedaan bermakna antara kelompok perlakuan dan kontrol pada post 2 dan post 3 (p<0,05; RR=0,69 [0,5310,896]). Simpulan, terdapat pengaruh penggunaan kursi persalinan BC-MK15 dan tempat tidur konvensional terhadap intensitas nyeri persalinan pada ibu multipara.
\end{abstract}

Kata kunci: Kursi persalinan BC-MK15, nyeri persalinan, tempat tidur konvensional

Received: 14 August 2017; Revised: 30 October 2018; Accepted: 23 November 2018; Published: 31 December 2018

Correspondence: Yetti Purnama, S.S.T., M.Keb. Department of Midwifery, Faculty of Mathematics and Natural Sciences, Universitas Bengkulu. Jln. Indragiri No. 4, Bengkulu City 38225, Bengkulu, Indonesia. Phone: +6281377520507. E-mail: yettipurnama123@gmail.com 


\section{Introduction}

Labor pain causes worry, strain, and anxiety so it increases the secretion of adrenocorticotropic hormone (ACTH), cortisol serum levels, catecholamines, decreases blood flow and increases abdominal muscle strain, this process will increase the perception of pain. Physiologically, work pain gets stronger along with the addition of the cervical opening and increased contractions of the uterus. ${ }^{1,2}$

The technique of reducing pain stimulation can be done through the mobilization and the upright position during labor. The birth chair is designed to facilitate the stage in the labor process which can facilitate a position change with a reclining design that can bolster the back firmly so it will cause relaxation, decrease catecholamines, increase the release of $\beta$-endorphins, block the transmission of pain stimulus and reduce the perception of pain. The upright position can reduce the pressure of the fetus which causes sores around and decreases abdominal muscle strain. The upright position is also utilizing the advantages of gravity effects through the decrease in aortocaval compression and the alignment of the fetus body with the birth canal so that intrauterine circulation will be better, preventing uterine ischemia and decreasing the pain sensations. Decreasing the intensity of pain during labor will affect the mother's psychological conditions, accelerate the labor process, and enhance the well-being of the fetus. ${ }^{3-9}$

The birth chair has been used to help the labor process for centuries. Various innovations of birth chair drafts have been conducted starting from the BirthRite to the AVE birthing bed that has already received an award from the Red Dot Design Award in 2003 and 2017. The draft of the birth chairs is changed in accordance with the changing times, but the principles and functions are still maintained. ${ }^{8-12}$

Study of Gizzo et al. ${ }^{12}$ showed that the maternity groups with the upright position have a lower pain level compared to the maternity groups with the supine position on the average score of $3.7 \pm 1.2$ and $7.1 \pm 1.6(\mathrm{p}<0.001)$. Rana' $\mathrm{s}^{13}$ study in Iran showed that during the first active phase with the upright position and supine position it indicates that there is a significant relationship between the position of women during labor to the level of pain in the lower back and abdomen $(p=0.000)$. The upright position can reduce back pain and abdominal pain can change the pain from the severe level to the medium level, and the medium level to the mild level at the first active phase of labor.

The result of the preliminary study is carried out in the Pelayanan Obstetri Neonatal Emergensi Dasar/PONED (Basic Emergency Obstetric and Neonatal Care/BEONC) Puskesmas (Public Health Center) of Bandung city, the facility that is used to aid labor is the bed that cannot facilitate the set up of the tilt back buffer to the maximum and cannot facilitate position change during labor. The result of the study conducted on $95 \%$ of women with maternity stated that the labor bed cannot help them change their position during labor so that the perceived increasing the pain. The rationale of the researchers are to plan and develop a tool that can facilitate the setup position of labor, i.e. Birthing Chairs-Magister Kebidanan 2015 (BC-MK15) which is more simple but has the same principle and function as the AVE birthing bed so it can be used by maternity volunteers in the community.

This study is implemented to analyze the difference in the effect of using BC-MK15 birth chairs and the conventional bed against the decrease in the intensity of labor pain in multiparous mothers.

\section{Methods}

The layout of the study uses the post-test only control group design. The selection of the sample uses the technique of consecutive sampling. This study used two groups, which were the treatment group (using BC-MK15) and the control group (using a conventional bed) and randomized by random permuted blocks. The study was implemented in PONED Public Health Center Garuda, Ibrahim Adjie and Puter of Bandung city in April until May 2017 and executed in sequential with other research teams which examine the appropriate technology of the BC-MK15. The sample was 60 multipara in the first active phase, each group consisted of 30 to treatments (using BC-MK15) and control (using conventional beds) which were taken to meet the inclusion criteria, i.e. the age of 20-35 years old, a multipara opening of $4 \mathrm{~cm}$, an aterm with singleton pregnancies, presentation of the head of the posterior fontanel in front, a pregnancy of 37-42 weeks, amniotic still intact, good uterine contractions, regular rhythm, frequency of 3 times in 10 minutes, 
no induction of labor, having a normal labor history, a fetal weight interpretation of $>2,500$ $\mathrm{g}$ to $<4,000 \mathrm{~g}$ and willing to be a respondent. Exclusion criteria: there were disproportions of the pelvic head, hemoglobin $<11 \mathrm{~g} / \mathrm{dL}$, mothers with a body mass index (BMI) of $<18.5$ to $\geq 30$, pregnancy with complications such as preeclampsia, eclampsia, antepartum hemorrhage and contraindications of pervaginam labor and no companion of labor. The criteria for drop out: the maternity that cannot hold the sense of labor pain, unable to continue pervaginam labor, partus presipitatus (precipitate labor), along labor and on the BC-MK15 or conventional bed $\leq 80 \%$ during labor. The pain score assessment used the visual analogue scale (VAS) in a cervical dilation of $4 \mathrm{~cm}$ (post 1), 7-9 $\mathrm{cm}$ (post 2) and 10 $\mathrm{cm}$ (post 3).

The analysis used in this study was the bivariate analysis. The characteristics of the data analysis used a chi-square test. Data normality is determined by the Shapiro-Wilk test and the see the box plot. The analysis of the difference between score posts 1, 2 and 3 in the treatment and the control group was performed by using the Mann-Whitney test because the data were in numeric form, abnormally distributed and presented in the median and percentile form. The effect of the birth chair on the intensity of labor pain in both groups was analyzed by using the chi-square test.

The protocol was approved by the Health Research Ethics Committee, Faculty of Medicine, Universitas Padjadjaran Bandung note number: 451/UN6.C.10/PN/2017.

\section{Results}

The subjects of the study were 60 respondents and divided into two groups, each group consisted of 30 respondents, i.e. Group A was a treatment group using the BC-MK15 and Group B used a conventional bed.

Table 1 determines the characteristics of two study groups, namely the education, economic status, parity, stations and birth weight. There

Table 1 Characteristics of the Study Subject

\begin{tabular}{|c|c|c|c|}
\hline \multirow[b]{2}{*}{ Characteristics } & \multicolumn{2}{|c|}{ Groups } & \multirow[b]{2}{*}{ p Value ${ }^{*}$} \\
\hline & $\begin{array}{c}\text { Treatment } \\
(n=30)\end{array}$ & $\begin{array}{c}\text { Control } \\
(n=30)\end{array}$ & \\
\hline Education & & & 0.529 \\
\hline Elementary school & 18 & 15 & \\
\hline Junior high school & 10 & 14 & \\
\hline High school & 2 & 1 & \\
\hline Economic status & & & 0.573 \\
\hline$\leq$ regional minimum wage & 22 & 20 & \\
\hline$>$ regional minimum wage & 8 & 10 & \\
\hline Parity & & & 0.881 \\
\hline 2 & 18 & 18 & \\
\hline 3 & 9 & 10 & \\
\hline 4 & 3 & 2 & \\
\hline Stations & & & 0.618 \\
\hline o & 9 & 6 & \\
\hline+1 & 16 & 17 & \\
\hline+2 & 5 & 7 & \\
\hline Birth weight (g) & & & 0.371 \\
\hline $2,500-2,999$ & 13 & 8 & \\
\hline $3,000-3,499$ & 14 & 17 & \\
\hline$>3,500$ & 3 & 5 & \\
\hline
\end{tabular}

${ }^{*}$ Chi-square test 
Table 2 Comparation of VAS Pain Scores in Both of Study Groups

\begin{tabular}{lccc}
\hline \multirow{2}{*}{ Pain Scores } & \multicolumn{2}{c}{ Groups } & \multirow{2}{*}{ p Value } \\
\cline { 2 - 3 } & Treatment (n=30) & Control (n=30) & \\
\hline Post 1: median (Q) & $3.5(3.00-4.00)$ & $4(3.00-4.25)$ & 0.184 \\
Post 2: median (Q) & $7(6.00-7.25)$ & $9(8.00-9.00)$ & 0.000 \\
Post 3: median (Q) & $10(9.00-10.00)$ & $10(10.00-10.00)$ & 0.002 \\
\hline
\end{tabular}

"Mann-Whitney test: post 1 (pain score cervical opening of $4 \mathrm{~cm}$ ), post 2 (pain score cervical opening of $7-9 \mathrm{~cm}$ ), post 3 (pain score cervical opening of $10 \mathrm{~cm}$ )

is no significant difference ( $\mathrm{p}>0.05$ ) between the groups.

The data normality test result with the Shapiro-Wilk data was abnormally distributed with a significance value of $\mathrm{p}>0.05$ and it was observed that the box plot data distribution results were not symmetric, the median was not precisely in the center of a square, there were also outlier and extreme values.

Table 2 determined that the pain score of the VAS in the post 1 was insignificant ( $p>0.005$ ), but in the post 2 and post 3 there were significant pain scores $(\mathrm{p}<0.005)$ between the treatment group (using the BC-MK15) and control group (using the conventional beds).

Based on observing Table 3 there was an influence of the BC-MK15 on the labor pain intensity of the post 3 (opening of $10 \mathrm{~cm}$ ) with a value of $\mathrm{p} \leq 0.05$. The relative risk calculation result obtained a value of $R R=0.69$, it means the chance of maternity of BC-MK15 users will be in a severe pain of 0.69 times during first active phase opening of $10 \mathrm{~cm}$ when compared to the control group.

\section{Discussion}

The characteristics of the two observed groups were education, economic status, parity, station (decrease of the head) and birth weight. The result of studying education characteristics, economic status, parity, station and birth weight in the treatment and the control group have no significant differences ( $p>0.05$ ), so both groups are homogeneous and comparable.

Birth pain is a complex, subjective pain, uncorfortable sensation or pain during birth. The perception of pain in every individual is different, how individuals perceive and interpret pain is influenced by various factors of physical, emotional, psychosocial, socioeconomic, cultural, education and environmental factors. ${ }^{1,14-18}$ In this study, the factors which affect the intensity of labor pain in addition to physiological factors such as education, social economy, and the parity of the study subject have no significant differences $(p>0.005)$ in both the treatment or control group.

Statistically, the results of the study, the difference in labor pain of multipara on groups that used BC-MK15 and groups that used conventional beds showed that there were significant differences in both groups. In the BCMK15 group, the statistical results of the MannWhitney test showed that there was no difference of the pain scale in the first post ( $>0.05$ ) this is due to many factors that influence the perception of pain including environmental factors, cultural and anxiety. At the opening of $4 \mathrm{~cm}$, the respondents have not yet adapted to the environment of the maternity room and the BC-MK15. The environment can affect the

Table 3 The Influence of BC-MK15 on the Intensity of Labor Pain in the Post 3

\begin{tabular}{lcccc}
\hline \multirow{2}{*}{ Group } & \multicolumn{2}{c}{ Post 3 } & \multirow{2}{*}{ p Value } & \multirow{2}{*}{ RR (95\% CI) } \\
\cline { 2 - 3 } & Very Heavy & Heavy & & \\
\hline Treatment & 20 & 10 & 0.002 & $0.69(0.531-0.896)$ \\
Control & 29 & 1 & & \\
\hline Based on two proportions of the first test side (chi-square), weight: VAS score & 7-9, very weight: VAS score 10
\end{tabular}


perception of pain, including the people in it, the room, and the facility where labor occurs. Women usually prefer to be treated by the health care personnel who are well known in a comfortable environment and remind them of their homes. The environment must be safe so that a woman can be herself while trying various things to improve her comfort. A comfortable environment will have an impact on the perception of pain during the labor process. ${ }^{1}$ The maternity environment settings have the opportunity to not have an anxiety of 2.5 times compared with maternity without the environment settings. Labor environment settings can take effect psychologically against mood and emotion, creates calmness, decrease maternal concentration towards the negative stimulus so that the mothers do not experience anxiety. ${ }^{17}$ In this study, the maternity are still in the latent phase carried out by observations in the same room with the maternity in the active phase so that the surrounding environment which is uncomfortable will affect the psychological and perception of respondents to the pain.

Cultural, racial and ethnical also factors also play an important role in pain tolerance and the nature of pain. Research data and clinical observations show the difference of race, cultures and ethnicities in the facing pain. Some races in the world show great pain expression, while other races do not show conduct that they are experiencing great pain. Certain cultures will affect a person's response to the pain. There are cultures that expresses the pain freely, but there are also cultures who consider pain as something that does not need to be overexpressed. ${ }^{1,18}$

On the second post (opening of 7-9 $\mathrm{cm}$ ) and the third post (opening of $10 \mathrm{~cm}$ in diameter), there were differences in the pain scale of both groups $(\mathrm{p}<0.05)$. This state indicates that the $\mathrm{BC}-$ MK15 can decrease the labor pain in multipara by facilitating changes in the position of each stage in the labor process that raises relaxation and decreases pain perception to create an increased sense of comfort in maternity with reclining backs which can be supported firmly. The tilt angle of the chair is in accordance with the principle of the upright position (avoid the supine position) which is above $45^{\circ}$ from horizontal. This position can facilitate relaxation because it can reduce abdominal muscular tension and improve ventilation through a dilation of the chest. Relaxation is believed to be able to increase the release of endorphins which block the transmission of pain stimulus and also stimulate large diameter A-beta nerve fibers thus reducing the transmission of pain through small fiber impulses of A-delta and C nerve fibers..$^{3-7,13,17}$

This is corresponding with the study of Smith et al. ${ }^{19}$ which stated that relaxation on patients can help reduce muscle tensions and emotional tensions as well as decrease the labor pain. The results showed that relaxation techniques can reduce the labor pain, in the first active phase, relaxation can relieve the pain and the pain level is very different in women who do not implement relaxation, relaxation is effective way to reduce the pain at all stages of labor.

The use of the BC-MK15 facilitates the upright position by utilizing the advantage of gravity effects through the decrease in aortocaval compression and alignment of the body fetus with the birth canal for better intrauterine circulation, preventing uterine ischemia. The upright position can also reduce pressure of the fetus and uterus in the nerve filaments to prevent the stimulation that will cause sores and reduce the sensation of pain. ${ }^{3-5}$ This is corresponding with Gizzo et al.' $\mathrm{s}^{12}$ study on two groups, the first group was the 69 maternities in the supine position and the second group was the 156 maternities in the upright position. The study shows that the maternity groups in the upright position have a lower pain level than the maternity in the supine position on an average score of $3.7 \pm 1.2$ and $7.1 \pm 1.6(\mathrm{p}<0.001)$.

The results of this study are corresponding with Rana's ${ }^{13}$ study of maternity in the first active phase with the upright position and a switch of every 15 minutes on the supine position which indicates that there was a significant relationship between the position of women during labor and the level of pain in the lower back and abdomen in the active phase of labor $(\mathrm{p}=\mathrm{0.000})$. The upright position can reduce back pain and abdominal pain, can change the severe pain to a moderate level, from a moderate to a mild level at one active phase of labor.

Results of this research also supports the research of Fitriani et al. ${ }^{20}$ in 30 maternal mothers which shows that the maternity time in the first active phase of the BC-MK15 was 250.44 minutes shorter than the conventional bed at 271.61 minutes $(\mathrm{p}=0.038)$. The second phase of the BCMK15 was 20.67 $\pm 2(1.02)$ minutes shorter than the conventional bed at 26.06 $\pm 2(1.08)$ minutes $(\mathrm{p}=0.001)$. The total maternity time of the BCMK15 was 269.42 minutes shorter than the 
conventional bed at 299.09 minutes $(\mathrm{p}=\mathbf{0 . 0 1 1})$.

The use of the BC-MK15 only managed to reduce the labor pain at the opening of 7-9 $\mathrm{cm}$ and $10 \mathrm{~cm}$ compared to using the conventional beds. The labor pain cannot be eliminated entirely because of many factors that cause the labor pain. The intensity of pain increases along with the increase of cervical dilation and much correlated with the intensity, duration and frequency of uterine contractions. The longer the perceived pain grows stronger, the stronger the peak pain that occurs on the active phase in the full opening of $10 \mathrm{~cm}$.

For further study, labor pain is a subjective factor that influences the perception of pain. Therefore, further study is needed to examine other variables that can affect labor pain such as variables of cultural and anxiety factors.

\section{Conclusion}

There are different effects of using the BC-MK15 compared to the conventional bed to the decrease of the intensity of labor pain in multipara mothers.

\section{Conflict of Interest}

All authors stated that there was no conflict of interest in this article.

\section{Acknowledgements}

Thanks to the Center for Quality Improvement of Human Resources for Health, Board of Development and Empowerment on Human Resources for Health, Ministry of Health Republic of Indonesia who have helped scholars for the implementation of this study. Thanks to the Politeknik Manufaktur Bandung and PT Kramatraya Sejahtera Cimahi who assisted the design and production of the $\mathrm{BC}-\mathrm{MK}_{15}$, and thanks to the BC-MK15 teams who have collaborated in this study.

\section{References}

1. Lowdermilk D, Perry S, Chasion KM. Keperawatan maternitas. 8th Edition. Singapore: Elsevier Mosby; 2013.

2. Labor S, Maguire S. The pain of labour. Rev Pain. 2008;2(2):15-9.

3. Angel Rajakumari G, Soli TK, Malathy D. Evaluation of the effectiveness of selected intervention in reducing level of pain perception and birth experience among primi gravida mothers. IJASR. 2015;1(4):182-5.

4. Krecow A, Zerbel J, Herbst P, Kupfermann A, Brophy JT. Maternity bed foot support and abduction assembly. Kalamazoo, Michigan: Stryker Corporation; 2006.

5. BerghellaV, BaxterJK, ChauhanSP.Evidencebased labor and delivery management. Am J Obstet Gynecol. 2008;199(5):445-54.

6. Janssen PA, Desmarais SL. Development and psychometric properties of the Early Labour Experience Questionnaire (ELEQ). Midwifery. 2013;29(3):181-9.

7. Adams ED, Bianchi AL. A practical approach to labor support. J Obstet Gynecol Neonatal Nurs. 2008;37(1):106-15.

8. Uryč M. BORCAD Medical, member of LINET Group SE, wins prestigious design award for innovative birthing bed [press release] (3 April 2017) [cited 4 June 2017]. Available from: http://www.linet.com/-/ media/Files/Website/linet/news/20170403Pressrelease-AVE2-wins-prestigiousdesignaward.ashx.

9. Thies-Lagergren L. The Swedish birth seat trial. Stockholm, Sweden: Karolinska Institute; 2013.

10. BORCAD. Birthing bed AVE. 2015 [cited 4 June 2017]. Available from: http:// www.alplermedikal.com/wp-content/ uploads/2015/12/Ave-Birthing-Bed.pdf.

11. Yap BL. The ergodesign of childbirth. In: Roozenburg NFM, Chen LL, Stappers PJ, editors. Proceedings of IASDR 2011: the 4th World Conference on Design Research; 31 October-4 November 2011. Delft, Netherlands: Faculty of Industrial Design Engineering, Delft University of Technology; 2011. p. 1-14.

12. Gizzo S, Di Gangi S, Noventa M, Bacile V, Zambon A, Nardelli GB. Women's choice of positions during labour: return to the past or a modern way to give birth? A cohort study in Italy. Biomed Res Int. 2014;2014:638093.

13. Rana D. The relationship between a woman's position during labor and the level of feeling pain in the active phase of labor. Life Sci J. 2012;9(4):422-5.

14. Khaskheli M, Baloch S. Subjective pain perceptions during labour and its management. J Pak Med Assoc. 2010;60(6):473-6. 
15. Shrestha I, Pradhan N, Sharma J. Factors influencing perception of labor pain among parturient women at Tribhuvan University Teaching Hospital. NJOG. 2013;8(1):26-30.

16. Charles C. Labour and normal birth. In: Chapman V, Charles C, editors. The midwife's labour and birth handbook. 3rd Edition. Chicester, West Sussex: Wiley-Blackwell; 2013. p. 1-48.

17. Pratiwi IG, Husin F, Ganiem AR, Susiarno H, Arifin A, Wirakusuma F. The effect of virtual reality on pain in primiparity women. IJNHS. 2017;4(4):46-50.
18. Rosdahl CB, Kowalski MT. Buku ajar keperawatan dasar. Volume 3. 10th Edition. Jakarta: EGC; 2014.

19. Smith CA, Levett KM, Collins CT, Armour M, Dahlen HG, Suganuma M. Relaxation techniques for pain management in labour. Cochrane Database Syst Rev. 2018;3:CDoo9514.

20. Fitriani, Mose JC, Herman H. Difference duration of labor at BC-MK15 birth chair with conventional bed in multiparous. GMHC. 2018;6(2):105-12. 